\title{
THE Forging of a White Gay Aesthetic at the Saint, 1980-84
}

\author{
Feature Article $\longrightarrow$ \\ TIM LAWRENCE \\ UNIVERSITY OF EAST LONDON
}

\begin{abstract}
An influential private party for white gay men that opened in downtown New York in 1980 and closed in 1988, the Saint was a prolific employer of high-profile DJs, yet their work has gone largely unanalysed. This article describes and contextualises the aesthetic of these DJs, paying particular attention to the way they initially embraced music recorded by African American musicians, yet shifted to a notably "whiter" sound across 1982 and 1983, during which time new wave and Hi-NRG recordings were heard much more regularly at the spot. The piece argues that this shift took place as a result of a number of factors, including the introduction of a consumer ethos at the venue, the deepening influence of identity politics and the encroaching impact of AIDS, which decimated the venue's membership. These developments led Saint DJs to place an ever-greater emphasis on the creation of a smooth and seamless aesthetic that enhanced the crowd's embrace of a synchronized dancing style. DJs working in electronic dance music scenes would go on to adopt important elements of this approach.
\end{abstract}

KEYwORDS: The Saint, DJing, whiteness, neoliberalism, AIDS

Tim Lawrence is the author of Love Saves the Day: A History of Dance Music Culture (1970-79) (Duke, 2003) and Hold On to Your Dreams: Arthur Russell and the Downtown Music Scene, 1973-92 (Duke, 2009). He is currently writing a book on New York club culture, 1980-84, again for Duke, and leads the Music Culture: Theory and Production programme at the University of East London. He is a founding member of Lucky Cloud Sound System, which has been staging parties with David Mancuso in London since 2003, and also of the Centre for Cultural Studies Research at the University of East London. For more information visit www.timlawrence.info or email tlawrence1@mac.com.

Dancecult: Journal of Electronic Dance Music Culture 3(1): 4-27

ISSN 1947-5403 @2011 Dancecult http://dj.dancecult.net

DOI 10.12801/1947-5403.2011.03.01.01

dsincecult 


\section{INTRODUCTION}

AtTracting AN AFFluent white GAY CROWD of 4,000-plus on peak nights, the Saint was probably the most prolific employer of DJs in New York City between 1980 and 1988, when it closed before opening for a much briefer run. Only the Paradise Garage, another private party that pulled in a predominantly ethnic gay crowd of 3,000-plus on peak weekend nights, rivalled the reach of the Saint during its 1977-87 run. However, whereas historians of dance culture have hailed the Garage's Larry Levan to be the most influential DJ in the city during the 1980s, the shifting roster of selectors who worked at the Saint have merited barely a single mention-an unlikely scenario given that privileged white groups often receive more attention than disadvantaged subaltern groups. ${ }^{3}$ Based on numerous interviews with key protagonists, documentary material held in the Saint's archive and recordings of DJ sets from the Saint, this article redresses the imbalance by outlining the contributions of Jim Burgess, Alan Dodd and Roy Thode, the Saint's principal DJs during the opening 1980-81 season, as well as Shaun Buchanan, George Cadenas, Michael Fierman, Robbie Leslie, Howard Merritt, Chuck Parsons, Terry Sherman and Sharon White, who appeared regularly in subsequent seasons. ${ }^{6}$ Thanks to their numerousness, none could come close to controlling the turntables at the Saint as the singular Levan did at the Garage, but their collective impact was considerable, even if their very collectivity also meant that each was ultimately disposable.

The article positions the Saint DJs not as isolated artists who developed their style in privacy before performing in front of a crowd, but instead as mediators of a taste culture who combined an expertise in music with a recognition of the need to satisfy the often complex and potentially contradictory desires of the Saint membership. If that need ran through 1970s dance culture in general, and has also defined many subsequent scenes, it took on a particularly pronounced character at the Saint, where a significant number of dancers came to express their opinions with unusual force thanks to the rise of an individualized consumer-is-right ethos that accompanied the high cost of entry, as well as the enormous value a certain cadre of gay men started to place on the enjoyability of their Saturday night. Convinced of the superiority of their own taste, these dancers practiced a form of critical connoisseurship that both strengthened their own elite status while establishing distance between the Saint and parallel scenes that were framed as being less discerning. In particular, dissatisfied dancers started to write letters of complaint to the management, and in so doing reframed the dancer (at least in those instances) as an individual consumer rather than a participant in a collective practice. Pressured by the management, the venue's DJs were compelled to respond, often by selecting more conservative records, and in an ironic twist, the Saint began to relinquish its cutting-edge status as a result.

Paying attention to the historical juncture, which witnessed the emergence of neoliberal economics, the intensification of identity politics and the onset of the AIDS epidemic, the article also traces the various ways the Saint DJs sought to please the crowd, as well as the related circumstances that led to the emergence and entrenchment of a white gay 
male aesthetic across the first four seasons of the venue's operation. The article also notes that although Saint DJs were nearly unanimous in their rejection of house music across the 1985-88 period, they helped pioneer an aesthetic that emphasized smooth blending and the matching of texturally similar tracks across an extended period of time, and therefore anticipated the sensibility that would later inform a significant proportion of DJ mixing in clubs that supported electronic dance music. Indeed once they acclimatized to the rougher, harder textures of early house, ex-Saint dancers were able to make a smooth transition to the Sound Factory, where Junior Vasquez, who declared Levan to be his primary influence, developed a trance-oriented repetitive style from 1989 onwards.

\section{The Setting}

Opened by theatre designer and St. Mark's Baths owner Bruce Mailman at 105 Second Avenue on the site of the old Fillmore East, the Saint surpassed the architectural ambitions of earlier private party venues that had attracted a near-homogeneous white gay crowd. Whereas the Tenth Floor and Flamingo added minimal design touches to the ex-industrial buildings in which they were located, the Saint's architectural aesthetic was rigorously futuristic and featured a hi-tech electronic coat check system, while the interior of the downstairs lounge area and the stairs that led up to the dance floor and the third-floor balcony area were built from concrete and steel. Lacking angles, the circular floor encouraged dancers to lose their bearings and open themselves to the unfamiliar. Above, a vast planetarium hood dominated the venue's stunning infrastructure, with the lighting operator able to draw on a vast array of effects that could transport dancers into different virtual environments.

Although the Saint was located in the heart of the multicultural East Village, the vast majority of its members were white, gay men who were comparatively well-off, which they had to be, because members paid $\$ 125$ for their cards and then $\$ 10$ per party, while guests had to be invited by a member and pay $\$ 18$ per party. ${ }^{11}$ The nucleus of the group formed first on Fire Island when revellers congregated at the Sandpiper, a discotheque located in the upmarket Pines, and they reconvened in Manhattan at the Tenth Floor, where the limited capacity led members to refer to themselves as "the 500", or the 500 most desirable (creative, stylish, attractive, successful, knowing, etc.) gay men in New York. After the sheer stress of managing the door contributed to the closure of the Tenth Floor, the growing contingent switched its allegiance to Michael Fesco's Flamingo, where they came to number more than a thousand and began to self-identify as "the A-list". Mailman then courted the group in the summer of 1980 and closed his membership list of 2,000 before opening night on 20 September. Flamingo regulars would recount that they had no choice but to switch allegiances when the new venue rose like a mirage.

The crowd might have been as racially homogeneous as any in New York. "The Saint was 95 percent white gay men", notes Sharon White, a DJ at the Pavilion on Fire Island as well as the Saint, and one of the tiny number of women to receive membership status. "Everything else fell into the remaining five percent, whether it be women, blacks or Latinos". ${ }^{12}$ The 
absence of black, Latino and Asian men was in fact less pronounced than it had been at the Tenth Floor and Flamingo. Terry Sherman, a Saint DJ, notes that a black friend of his called Duane was "one of Bruce's regular dancing partners", and adds that during the period he had three black boyfriends, all of whom would head to the Saint, irrespective of whether he was DJing that night or not. ${ }^{13}$ "It was a bigger club, so there was more room, so of course you saw more blacks", says the Peruvian-born Jorge La Torre, a regular at the Tenth Floor and Flamingo before he defected to the Saint. "I think black men also felt more welcome, and you began to see white men with black lovers. But if you saw a handful of black people that was a lot". ${ }^{14}$

If the low turnout indicates that many black men still didn't feel welcome, it remained the case that to a significant extent the Saint and the Garage subdivided according to a combination of sexual attraction and musical preference (with black and Latino gay men heading to the Garage if their sexual preference was for black and Latino men, etc.). Moreover, the hierarchies that kept poorer black and Latino dancers out of the Saint can in part be attributed to what Sherman calls "societal racism", and not Mailman's need to introduce a business model that would enable him to repay the approximate $\$ 3-6 \mathrm{~m}$ cost of opening the venue. ${ }^{15}$ "Should Bruce have initiated an affirmative action policy like "White Males \$10, African Americans Free' and put on chartered buses from 125th Street, Bed Stuy [Bedford-Stuyvesant, Brooklyn] and the Bronx to the Lower East Side?" asks Sherman, who struck up a strong friendship with Mailman. "Maybe. But Bruce didn't care who came and there was no racial profiling [or membership policy that excluded black and Latino men] specific to the Saint". ${ }^{16}$

There was, however, sex profiling, with women excluded on the grounds that they would compromise the gay male dance ritual if they were allowed to occupy anything more than the very outer margins of the venue. According to Leslie, who previously DJed at 12 West, a comparatively mixed gay private party located underneath the Westbound Highway on West Twelfth Street, the policy grew out of Mailman's belief that "gay men danced well together" and that women would disrupt this collective energy because they used their bodies differently. ${ }^{17}$ In contrast to the plurality of expressive styles that could be witnessed at the Loft and the Paradise Garage, the resulting dance dynamic forged a form of locked-in conformity that evokes Walter Hughes' description of the depersonalised white gay disco dancer as "becoming an extension of the machine that generates the beat" (1994: 151).

"The Saint seemed almost synchronized", comments La Torre. "If someone was doing a certain move, the others would start to follow. They would go along with whatever it was that was going on". Creating an interconnected, amoeba-like organism that mutated in barely perceptible ways, dancers moved within constrictions set not only by the disciplinary injunctions of the beat, as suggested by Hughes, but also within a general social code that discouraged men who came from a white, Anglo-Saxon, Protestant background from expressing themselves physically, irrespective of their sexuality. Added to that, Saint dancers also contended with a more specific macho code that gained currency in New York in the late 1970s that led gay men to rein in the way they would use their bodies. "The goal was 
the moment of unity, the moment when everything disappeared, when time and space disappeared", explains La Torre, who would also head to the Garage on a fairly regular basis, and notes that dancers there were significantly more expressive. "It was just pure energy. It was extremely welcoming and extremely powerful. Within it everything seemed possible". ${ }^{20}$

\section{DJING}

Whereas DaVid Mancuso was inseparable from the Loft because the party was situated in his own home, and Larry Levan was all but inextricably tied to the Paradise Garage because Michael Brody built the venue around his appeal, Mailman concluded that it made better business sense for him to encourage his dancers to form an attachment to the venue rather than any single DJ. As a result, he introduced a revolving roster of DJs from the outset, and established a broader framework that positioned DJs as hired entertainers whose primary function was to serve the community and the setting. The break with previous employment practice, in which DJs would seek out residencies where they would play on a regular basis until they fell out of favour with the dancers or the management, was marked, with Mailman instituting a framework in which they could expect to play once or twice a month if they were lucky. As such, their status as freelancers was embedded ahead of the more general shift towards one-off, flexible contracts-a shift that would become one of the hallmarks of market-driven neoliberalism. "After Flamingo closed things really changed", comments Howard Merritt, a Flamingo resident who went on to play regularly at the Saint. "None of the big clubs had an in-house disc jockey. You had your calendar and you'd get called by the clubs, and gradually you would fill in the nights". ${ }^{21}$

If the development threatened to undermine the ability of the Saint roster to form a deep bond with the dance floor, that possible consequence was countered by the fact that Mailman's DJs played ten-hour-plus sets that encouraged emotive ties to be formed. While Mailman also believed that the huge cost of his venture required him to institute a system that guaranteed his dancers wouldn't become bored by a single in-house DJ, he also drew regularly on a delineated pool of principal DJs, as well as a secondary pool of up-and-coming selectors to perform on weekdays and sometimes on Sundays, which were less busy. For their part, the DJs acquired the aura of orchestra conductors; their names would be advertised in advance, and it became established practice for a spinner to pause at around six o'clock in the morning, at the peak of the night, in order to receive applause from an audience that was largely familiar with the ovation rituals of New York's theatres and concert halls. After that, the DJ got to stretch out during an extended encore that would often last for four hours or more. Within the core roster, a consensus emerged that the Saint wasn't necessarily the nicest or warmest environment in which they could work, but performing there nevertheless marked a career pinnacle, and also bestowed them with the kind of cachet that could lead to further job offers elsewhere.

Of the principal DJs who played the opening season-all three were members of Judy Weinstein's For the Record, the most prestigious record pool in the city-Alan Dodd 
was the smoothest, and "could play a whole night like glass", says Leslie. For his part, Roy Thode was a busier, trickier mixer who liked to cut back and forth between two back-beated copies of the same record to generate an echo effect, execute extended mixes using two separate recordings and introduce reverb effects. "Roy could take apart and restructure it better than anyone", comments Marsha Stern, a close friend of Thode and one of the few women to hold a Saint membership card. "We would tease him and say he was getting too knobby, but the rearranging was part of the art form. He had an innate sense of magic making and a real rapport with the crowd. People would come up to the booth and say, 'It's just a wonderful party". ${ }^{22}$ Jim Burgess, a prolific studio hand who mixed records such as "I Love The Nightlife (Disco 'Round)" by Alicia Bridges, "A Lover's Holiday" by Change, "Runaway Love" by Linda Clifford, "Secret Love Affair" by Madleen Kane, "The Beat Goes On And On" by Ripple and "Da Ya Think I'm Sexy" by Rod Stewart, was more mercurial than Dodd and Thode. "Jim Burgess was probably the most talented mixologist", comments Leslie. "Sometimes he was on and sometimes not. But when he asserted himself nobody could touch him for technique".

Signalling his retirement in advance, Burgess played his last party on 31 January 1981, yet instead of letting the night run its regular course, he walked out of the booth in high style at 6:00 AM with the crowd in a state of rapture and nowhere else to go. Near to the booth at the time, White was called on to step in, and after grabbing some records from the on-site apartment of the principal lighting designer and operator Mark Ackerman, she approached the turntables like a boxer moving through a parting crowd, and proceeded to rescue the party. Her performance vindicated the earlier decision of Ackerman (a close friend) to schedule her to play in March; Mailman had opposed the move, but backed down when Ackerman, a hugely influential figure, told him he would resign if he overruled the booking. Proud of her ability to play "outside of the box", White joined a roster that included Leslie, a consummate professional and hugely popular figure whose style emphasised smoothness and tonality, as well as Chuck Parsons, who favoured a harder, faster aesthetic. "Chuck was never a favourite with the crowd, but Bruce loved what he played and he got almost all of the big parties from 1982 to 1986", comments Sherman. "It also helped that he was a brilliant technician and almost never had a bad mix".25

All of the Saint DJs sought to forge an arc that resembled the affective flows enjoyed in other clubs, yet was more precisely calibrated in terms of tempo and energy. Often beginning with an orchestral recording, which would enable them to "tune" the room while making a statement about their sophistication and tastefulness, they would go on to play bright mid-tempo songs to invite people onto the floor and set a positive tone. From there the DJs would build to the peak period that ran from about 2:00-6:00 AM, and involved them selecting higher-tempo tracks that scampered along at 125 BPM upwards. "There would be a series of peaks", comments Michael Fierman, who got his break through the Hot New Talent Night, which Mailman inaugurated on 12 May 1982, and went on to become one of the venue's most influential spinners. "But you couldn't play 100 hits in a row, each one an increment better than the other, so to build the excitement one had to pull back to get 
to another peak". ${ }^{26}$ At around 6:00 AM, in a ritual that was not replicated in other venues, the DJ would let the final record of the peak set fade, accept applause from the crowd and acknowledge the work of the lighting person and the generosity of the crowd (if indeed the applause was enthusiastic, which wasn't always the case). After that, the DJ would take the tempo right down and play a set that was commonly referred to as "sleaze" or "morning music".

More than other crowds, Saint dancers demanded that their DJs generate "a very smooth flow" (in the words of Leslie) as well as turn to certain records during peak of the night. ${ }^{27}$ "It's not like the DJs were clones of each other, but we were expected to play the things that were popular with the crowd at that particular moment", comments White. "I used to say that we all played the same records, but in a different order". ${ }^{28}$ While the taste of some Saint DJs might have coincided seamlessly with what the crowd wanted to hear, White maintains that the crowd's preference would take precedence when there was a discrepancy, and she felt compelled to play "filler" tracks that were beyond her "scope of appreciation" between the hours of 2:00-6:00 AM. Evoked as being equal when Leslie talked about the existence of a "third-person consciousness" in a 1983 interview (Park 1983: 37), the dancing crowd was in fact more powerful than the DJ during the middle part of the night, after which the initiative reverted back to the DJ during the elongated "sleaze" or "morning" session, because the crowd had been satiated by then. "You were expected to take a left turn because you'd given them all they expected", adds White. "We shined as individuals after 6:00 AM. Before that, anybody could have been playing".

Saint DJs also had to operate in the conditions that characterised the post-disco sucks era. As has been described in detail elsewhere, the overproduction of disco music in the aftermath of the success of Saturday Night Fever combined with the onset of a deep recession that enabled right-wingers to link the perceived decline of the United States with the advances made by the countercultural coalition of the late 1960s, led to a homophobic, racist and sexist backlash against disco that positioned the culture as the overdetermined source of the crisis facing white straight men. ${ }^{29}$ Felt most keenly in suburban areas and the boardrooms of major record companies, where executives were demographically inclined to favour rock above disco, the backlash resulted in the "disco" nomenclature falling into disuse and the dramatic cutting back of production. But in urban centres such as New York and San Francisco public clubs and private parties continued to attract significant numbers of dancers, and this vibrant network provided independent record companies with a core market that was focused, enthusiastic and hungry for innovation. Along with venues such as Bond's and Danceteria, the Saint opened shortly after the majors (with the partial exception of Warner Brothers) decided to withdraw from the disco market. As a result, its DJs turned with renewed interest to the release schedules of New York's and San Francisco's independent sector, as well as the import recordings that could be found in specialist stores such as Vinyl Mania.

The Saint DJs played US synth pop tracks such as "Gloria" by Laura Branigan and "Stormy Weather" by Viola Wills. They drew on the rich seam of high energy music that was being 
released by West Coast labels such as Megatone and Moby Dick, many of them recorded by Patrick Cowley, Sylvester and the Weather Girls, with "Do You Wanna Funk" and "It's Raining Men" two of the most popular tracks (at one point during 1982, Brian Chin [1982: 48], the dance columnist for Billboard, went so far as to wonder if Eurodisco had "emigrated" to San Francisco). They turned to up-tempo R\&B-oriented tracks including Sharon Redd's "Can You Handle It?" They looked towards Europe and Canada (where the backlash against disco was less severe) and integrated cuts from ABBA's album The Visitors as well as recordings such as "Hit 'N Run Lover" by Carol Jiani, "Step By Step" by Peter Griffin, "Feels Like I'm In Love" by Kelly Marie, "Don't Stop The Train” by Phyllis Nelson, "Hot Leather" by the Passengers and "The Hills Of Katmandu" by Tantra. Conscious that they were the progeny of the white gay DJs and dancers who helped popularise disco, they also continued to play a significant proportion of disco and late disco classics, including Cut Glass's "Without Your Love”, Jimmy Ruffin's “Hold On To My Love”, Marlena Shaw's "Touch Me In The Morning" and Voyage's "Souvenirs" among the most popular.

The mix grew out of the matrix of 1970s New York dance, which foregrounded sonically polycultural sounds, even in settings that were tightly defined demographically. That applied to the Tenth Floor, where the African American DJ Ray Yeates drew on cuts by outfits such as the Equals and the Staple Singers, and also Flamingo, where Michael Fesco employed the Puerto Rican Richie Rivera to offset Howard Merritt's sweeter, more melodic selections with rumbling rhythm sections, esoteric jazz progressions and angular synthesizer workouts. At the Saint, White along with Steve Williams maintained an ethnic presence in the booth-they were joined by the alternate lighting operator Richard Tucker, who was also black - and along with Burgess, Dodd and Thode, White drew liberally on music recorded by African American musicians. Thode was particularly notable for his embrace of jazz and $\mathrm{R} \& \mathrm{~B}$ oriented selections, and in his personalised notepad of favourite records, titled "The BPM (Beats per Minute) Bible", listed groups such as Donald Byrd, Chic, Manu Dibango, Earth, Wind \& Fire, First Choice, Aretha Franklin, Instant Funk, Taana Gardner, Gwen Guthrie, Isaac Hayes, Herbie Hancock, Nona Hendrix, Loleatta Holloway, Grace Jones, Chaka Khan, Gladys Knight, Kool \& the Gang, Stefanie Mills, Northend, the Pointer Sisters, Sharon Redd, Sister Sledge and Sparque, along with more obvious choices such as Donna Summer, Sylvester and Two Tons o' Fun. All of these artists were just as likely to be heard in an ethnically mixed venue. ${ }^{18}$

The tastes of the DJs were related to their cultural experiences, and Thode along with White were grounded in the disco era, when $\mathrm{R} \& \mathrm{~B}$ and funk were prominent influences, and when clubs and sounds were more likely to be both racially and sexually mixed than would prove to be the case in the more sedimented decade of the 1980s. At the annual Black Party (effectively a leather party) held in early 1981, Thode demonstrated that his taste remained rooted in the ethos of the 1970s when he opened his set with records such as Ozo's mystical percussion-chant "Anambra", Taana Gardner's heavy R\&B groove "Heartbeat" and Sharon Redd's optimistic R\&B workout "Can You Handle It?", which he juxtaposed with "Passion" by Rod Stewart and "Magic" by Olivia Newton-John. 


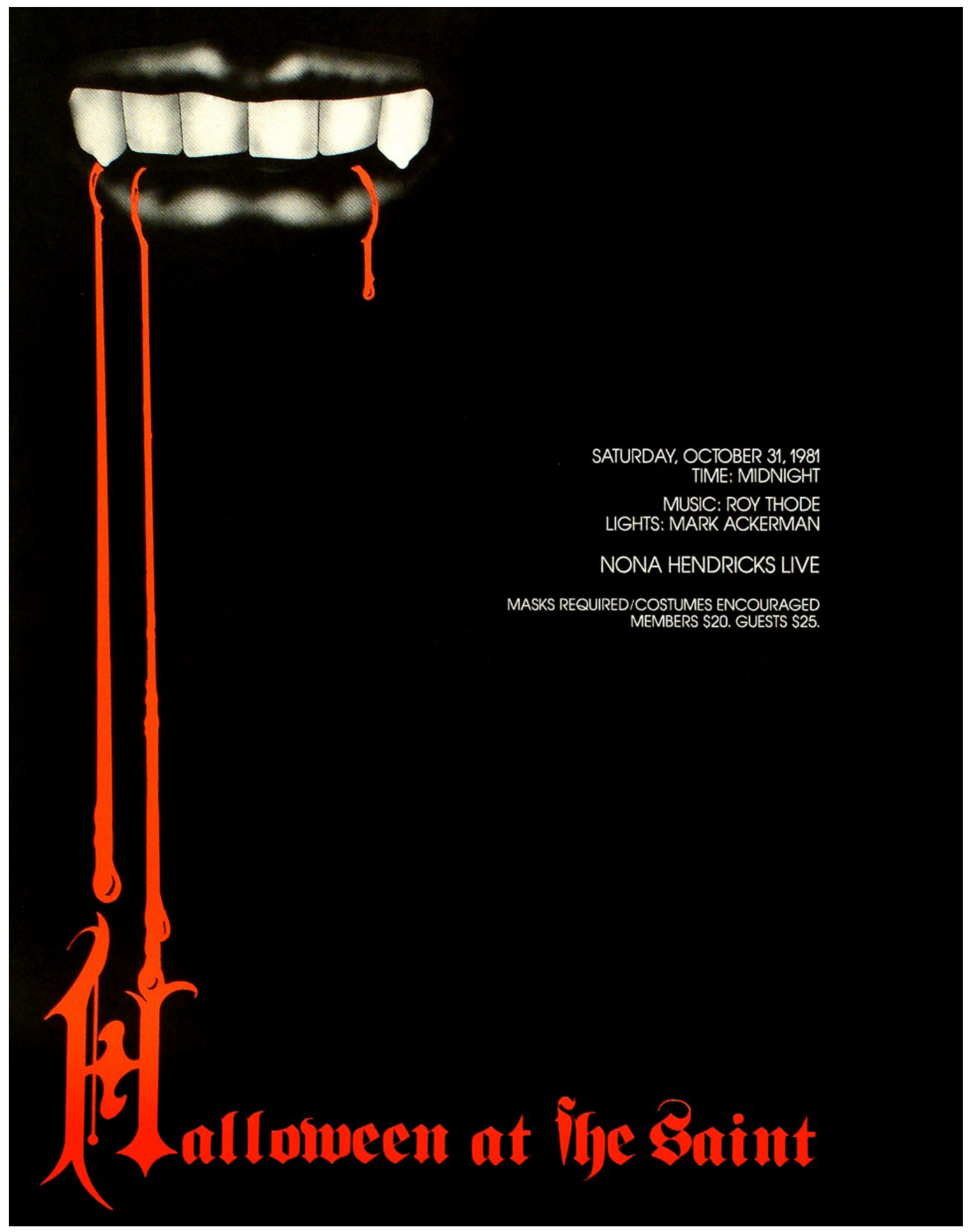

Figure 1. Roy Thode DJs at the Saint's Halloween party, 31 October 1981. Courtesy of Stephen Pevner. 
Maintaining the mix throughout the night, Thode opened the fourth hour of his set with a rapped version of "Walk The Night" (by the Bent Boys), the Talking Heads' Africanist "I Zimbra" and Karen Young's R\&B disco anthem "Hot Shot", which he followed with the playful, bubbly "Feels Like I'm In Love" by Kelly Marie. ${ }^{19}$ The extent to which Thode's selections overlapped with those of Levan and Mancuso is elided by Buckland (2002: 68) and Shapiro (2005: 74-6), who note that the Saint's soundtrack consisted of Hi-NRG and new wave tracks, while Brewster and Broughton's (1999: 312) argument that the Saint DJs "favoured a very particular sound, playing melody-soaked songs with a heavy kick-drum, richly orchestrated strings and sentimental lyrics" also underestimates the range of the venue's early DJs.

\section{Pressures}

DRAMATIC SHIFTS in the makeup of the Saint roster nevertheless augured an increased emphasis on the sounds of Eurodisco, new wave and Hi-NRG, which were associated with the historically contingent preferences of a subsection of white musicians and listeners. First, shockingly, Thode died of a drug overdose in May 1982, and while nobody can be sure if he committed suicide, he had attempted to take his life previously and was feeling particularly low before the incident. Thode's close friend Marsha Stern, very possibly the last person to see him alive, notes that the DJ had had a major argument with his boyfriend shortly before the overdose, and confirms the opinion of some of Thode's DJ peers that he was also highly sensitive to the opinions of dancers. ${ }^{20}$ "Being the DJ made him the butt of everyone's comments", remarks Stern. "He might have played brilliantly, but if the guy writing the editorial page in a magazine happened to have a lousy time, maybe because he had some bad drugs, he could be quick to hand out a lashing. There were also some nasty-ass queens who would write letters. Roy even received hate mail. These people are nuts, but if you're a little too sensitive, you can let that get to you". ${ }^{21}$

Mailman organised a tribute party, and then appears to have told Leslie and White separately that he expected them to assume Thode's mantle as the main attraction at the Saint (meaning the DJ who would draw in the biggest crowds, and also provide the venue with a sense of aesthetic direction). Both DJs were given prominent roles when the club opened for its third season in the autumn, but the equilibrium was short-lived: Leslie was handed a contract that secured his commitment to the Saint, while White was told that her services were no longer required around the spring of 1983. "Bruce just didn't feel that I was doing my best", she recalls. "I don't know whether it was because I was playing what I wanted to play, or whether he thought I was lazy. He just fired me". She adds: "The responsibility got to be too large for the reward. It got to be a pain in the ass. So I was more than willing to say, 'Whatever".

The pressure was intense, not simply because of the size of the crowd, but also because individuals and clusters of individuals became increasingly ready to criticise specific DJ performances by writing to Mailman, or if they were part of the core group that knew 
Mailman personally and were the first to sign up to his membership scheme, speaking with him directly. "People measured success by how satisfied they were at the end of the night", comments La Torre. "Had they had a peak experience? If they had, they went home happy. If they didn't then they blamed the DJ. I am not certain people actually meant it; they were not critical enough or observant enough of why sometimes it happened and why sometimes it didn't. But I heard it from everybody. It was just the thing to say". Mailman respected his DJs, but depended on the financial support of his heavily mythologized A-list membership, and having benefited from the critical judgement that the Saint was superior to Flamingo, he began to present letters of complaint to DJs who were perceived to have had an off-night and asked for an explanation in order to protect his venue's status.

As long as the Saint came out "smelling like a rose", Mailman would back the DJ, comments White. But repeated complaints could lead to a DJ being struck off the roster, and before Mailman sacked White he asked her to monitor Wayne Scott, who was judged to be unpredictable; at the end of his final set, Scott played the resonant "Town Without Pity" by Gene Pitney. George Cadenas experienced an even more abrupt ending when he played "White Rabbit" by Grace Slick and the Great Society at the peak of a party and witnessed the record to fall flat. "It didn't happen, and that was the end of him", recalls Merritt, who concluded that playing to the best of his ability was no longer sufficient, and took to calling up drug dealers to find out what had been selling in the run-up to the weekend so he could tailor his selections accordingly. "If you had a bad night you never got asked back", adds Merritt. "One disk jockey might play two Saturdays, and if the second night wasn't so good, the inner circle would go to Bruce, and the DJ wouldn't be booked the next month".

Leslie and Sherman insist that Mailman didn't want his DJs to play a narrower and safer range of records, and although Merritt perceived him to be clamping down on artistic freedom when he asked them to start preparing playlists in advance, the owner apparently believed the strategy would encourage the introduction of a broader range of sounds than might have been the case if DJs responded only to the immediate demands of the crowd. The favour shown to someone like Shaun Buchanan supports Leslie's position, as do off-the-record conversations in which the owner would rally against the relative conservatism of some of his DJs. Nevertheless, the value attributed to the letters of complaint could encourage DJs to frame their risks within a specific horizon, and the unceremonious sacking of Cadenas, Scott and White increased the impression that performances were being surveilled. The precise relationship between Thode's death and the letters of complaint must remain unknown, yet across 1983 and 1984, DJs tailored their selections with increasing precision to the expectations of a crowd, which hankered for an arc of seamless intensification, and favoured sounds that were heavily electronic, rhythmically monosyllabic, harmonically adventurous and high tempo because those elements enhanced their perceived journey into a collective parallel consciousness. 


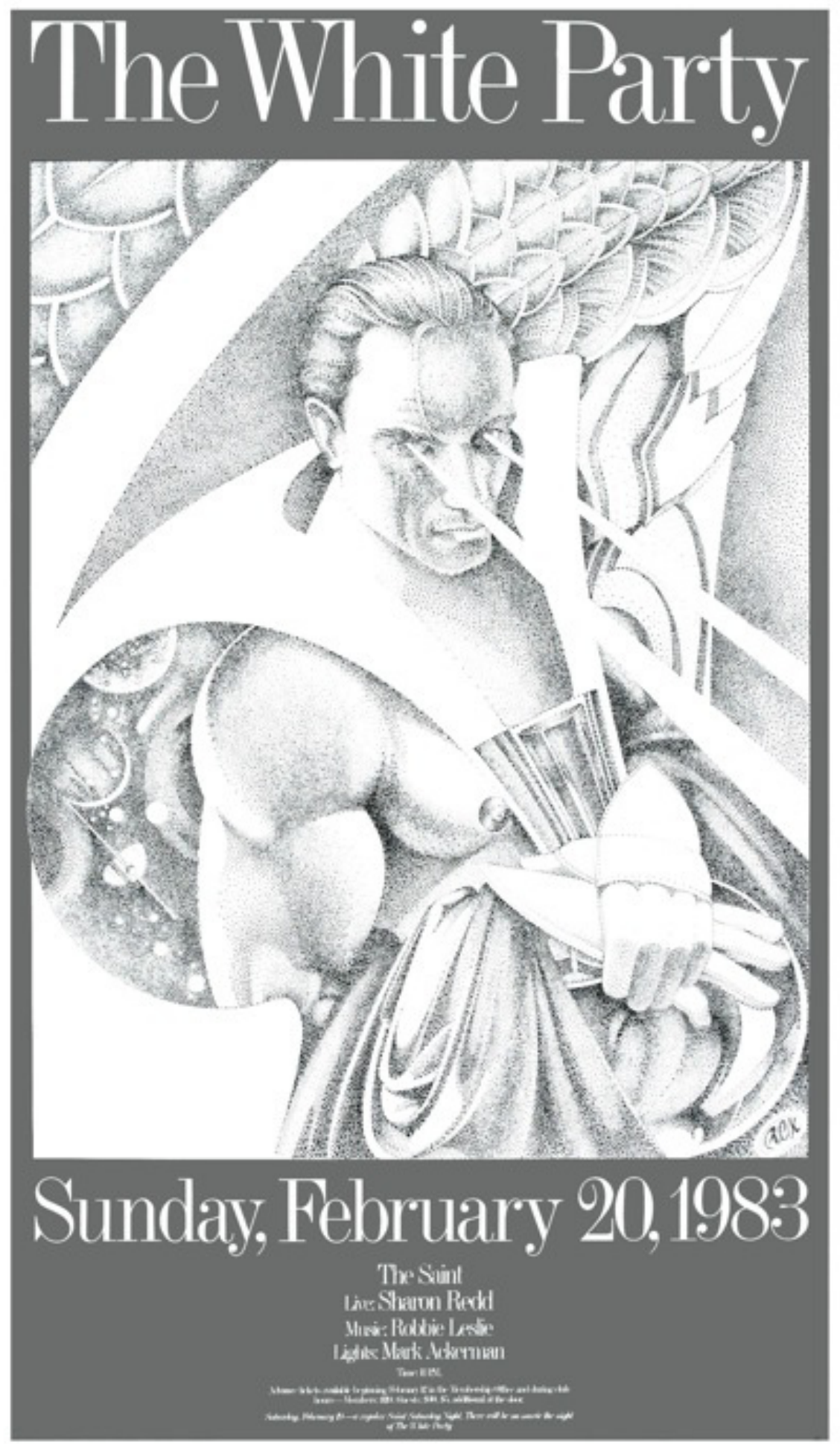

Figure 2. Poster for the White Party, 20 February 1983, featuring Robbie Leslie. Courtesy of Stephen PeVner. 


\section{AESTHETIC OF WHITENESS}

After Roy, new DJs came in with new flavours", notes Stern. "Michael Fierman didn't have as much of an R\&B flavour to his music, and nor did Michael Jorba. Michael would play OMD, more rockish stuff, more heady stuff, and so there was a different complexion to the music". She adds: "Alan Dodd, Howard Merritt, Robbie [Leslie] and to a certain extent Jim Burgess were known for being more white-sounding compared to Richie Rivera and Roy [Thode]. But all of those DJs played a lot more R\&B than some of the newer DJs". ${ }^{22}$ According to Sherman, Buchanan and Parsons pioneered the playing of ultra-fast dance tracks that were rock rather than disco-tinged, including "That's Good" by Devo, "White Wedding" by Billy Idol, "Now You're Mine" by Giorgio Moroder with Helen Terry, "Twist Of Fate" by Olivia Newton-John, "City Of Night" by Rational Youth, "Dancing In The Dark" by Bruce Springsteen, "Jump" by Van Halen and "Holding Out For A Hero" by Bonnie Tyler, along with new wave tracks by the Associates, Blancmange, China Crisis, The Comateens, A Flock Of Seagulls, The Lotus Eaters, Orchestral Manoeuvres In The Dark and Spandau Ballet. Other popular import tracks included "La Noche (The Night)" by Azul Y Negro and "Come And Get Your Love" by Lime. From 1983 onwards, Saint DJs also started to play European Hi-NRG tracks such as "So Many Men, So Little Time" by Miquel Brown and "High Energy" by Evelyn Thomas (the death of Patrick Cowley from AIDS in 1982 having slowed the output on the West Coast).

The point wasn't that these records were "white" so much as they weren't counter-balanced by records that suggested a complementary set of cultural allegiances, and across 1983 and 1984 Saint DJs played very few if any records that could be heard at the Garage. If that also confirms that Levan selected equally few tracks that could be heard at the Saint, the Garage was nevertheless less isolated than its Second Avenue counterpart because Levan's tastemaking role extended beyond the black gay network, whereas Saint spinners didn't appeal beyond the white gay scene. For sure, elements of the narrowing Saint aesthetic could be heard outside of the white gay network, and English new wave was played heavily at spots such as Danceteria, which were inappropriately labelled rock-dance clubs. However, DJs such as Mark Kamins (perhaps the most influential selector at Danceteria) weren't taking their cues from the Saint, and they also steered clear of the high tempo selections that Saint DJs would play between 2:00-6:00 AM.

An increasingly prominent figure during 1983, Fierman maintains the "unification of the room" was his "main goal", and along with other spinners he would maintain a steady energy until, usually around two or three in the morning, he would introduce the first of a series of anthems that would generate a mini-surge from the basement and the peripheral areas onto the floor. After that, he would punctuate his selections with additional "anthems" that would generate "evanescent convergences" in which everyone would "feel connected". ${ }^{23}$ Barry Walters, a Mudd Club and Danceteria regular who went to the Saint as well as the Paradise Garage for the first time in 1983, was struck by the uniformity of the aesthetic. "Larry and Mark Kamins and Justin Strauss and Anita Sarko didn't mix smoothly and they 
also brought a lot of different styles into the mix", he recalls. "At the Saint the mixes were much smoother and the variations between the records were almost infinitesimal. It was the first time I encountered a style of DJing where one record was only slightly different from the record I'd just heard". ${ }^{24}$ La Torre was keenly aware of the reason for the manicured smoothness of the style. "Even though the records might sound repetitive, that was just because the DJ wanted to make the moment last", comments the dancer. "The DJs would drag the same beat for what seemed like a very long time, just to maintain that feeling, that peak experience". However, La Torre adds that by 1986 the sound had become "so white" and "defined" it began to turn him off. "I was not pleased with the music, and the vibe was becoming just a little too chemical", he recalls. "It was not really soulful and it didn't have that Latin or black beat. They had distilled it so much the sound became boring by 1986 ".

The distillation process assumed its shape across 1983 and 1984, and when Mario Z (1984) interviewed Leslie for the New York Native in March 1984, the DJ acknowledged that the Saint sound had indeed started to congeal. "Music has evolved but New York's gay market has faithfully held on to the romantic period of disco, which was 1978 through 1980", the DJ commented (Z 1984: 21, 24). "While we've all been dancing to that, we haven't noticed that there are a lot of records being produced that over the past couple of years we've ignored because they haven't fit into the mold that the audience has demanded". By this point, Leslie had emerged as the venue's pre-eminent draw, and in a June 1983 interview with the spinner the Saint cashier Jan Carl Park (Park 1983: 36) made much of his pre-eminent appeal. Strangely reticent in his interview with Z, Leslie emphasised the need for aesthetic renewal, and argued he couldn't "remain stationary", even though some members resented his "pushing ahead", because if he did "everyone is going to wake up and find that they're terribly bored".

Having started to play at the Saint during the 1983-84 season, Sherman drew on records that were deemed to be funky, including "Padlock" by Gwen Guthrie, "Clouds" by Chaka Khan, "Square Biz" by Tina Marie, "White Lines" by Melle Mel, "You Don't Know" by Serious Intention and "No Favors" by Tempers, and he also pitched down anything that ran at $136 \mathrm{BPM}+$ because "it made some of the records that were really bad sound a bit less cheesy". "It's sort of a myth that all anybody wanted to hear were things like 'Heaven Must Have Sent You' by Bonnie Pointer or 'Tripping On The Moon' by Cerrone”, he argues. Then again, Sherman notes that he owed his position to the fact that Mailman "liked the fact I was not afraid to play 'unusual things', even though some of the crowd might not like them". ${ }^{25}$ Leslie, meanwhile, sought to renew the Saint's aesthetic by introducing new wave tracks alongside the more refined end of Hi-NRG and Italian dance imports, which he continued to pepper with classic disco. But looking back, he notes: "Overall we were walking on a cliff edge musically at the Saint and product was running scarcer by the week. I felt a feeling of imminent disaster". ${ }^{26}$

The shift towards a white-identified aesthetic coincided with wider shifts in identity politics, which proposed that marginalised citizens should act not as self-interested individuals but instead within like-minded groups. Growing out of the countercultural 
movements of the 1960s, and refined when the black lesbian feminist group the Combahee River Collective (1977) published a statement of aims that reflected on their common material experiences and objectives in 1977, identity politics challenged the idea that history should be driven by internally cohesive nations. Immanuel Wallerstein (1983: 159) drew attention to the shift when he remarked on the way people were beginning to seek the protection of groups that were deemed to be both equal in status yet also particular in composition, and his argument sheds light on the Saint. After all, the poster for the opening night party featured a cyborg-like figure of St. Sebastian with lasers shooting out of his fingertips and eyes, and therefore depicted the Saint dancer as a figure of persecution, righteousness and beauty who could experience redemption and transcendence through the assertion of his homosexual identity on the dance floor (and this before AIDS was reported in the media). Following the turbulence of the 1982-83 season, the 1983-84 season might have marked the moment when the membership acquired a settled sense of itself. And over time, the infrastructure of the venue also appears to have exerted a cumulative influence on the contours of the music, with DJs increasingly tuned to the ease with which smooth, shiny, futuristic sounds complemented the contours of the building. Dancers and spinners proceeded to coalesce around a sound that was so distinctive it couldn't be heard in any parallel dance milieu.

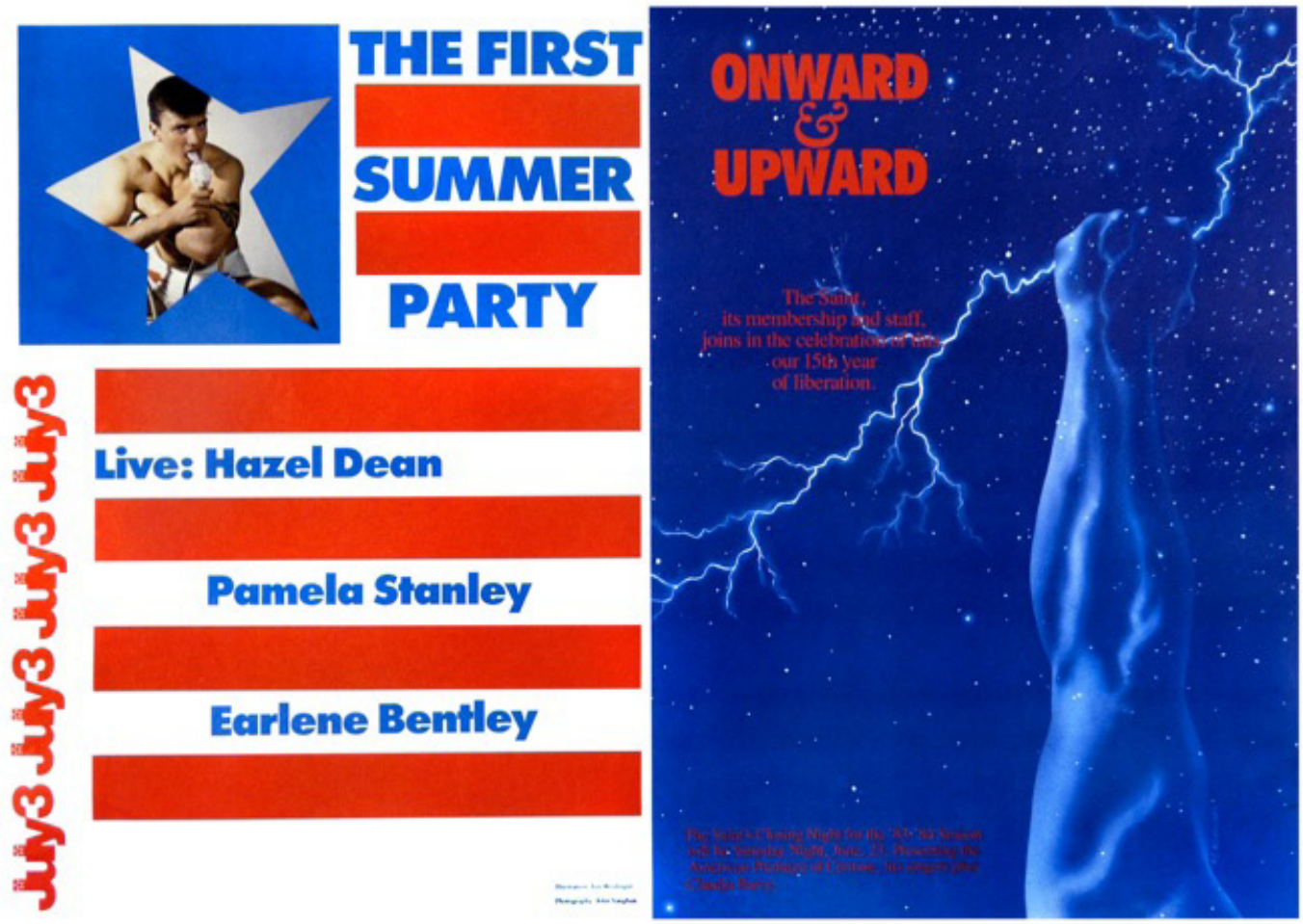

Figure 3. Liberation at the Saint, as depicted in a PUblicity poster, 3 JULy 1983. Courtesy of Stephen PeVner. 


\section{CONSUmer Culture AND AIDS}

THE MARKED ACCELERATION of consumer culture during the 1980s-which culminated in "hyperconsumption" (Ritzer 1999) - also enabled people who enjoyed relatively easy access to cash or credit to experience and shape their identity through the practice of buying objects or experiences in a way that was historically unprecedented. This articulation of consumer-identity was particularly marked at the Saint, where the enormous investment that went into the development necessitated high entry prices. The Saint was therefore characteristic of what Arjun Appadurai (1996: 115) describes as the 1980s rupture with the preceding decade, inasmuch as Mailman's venue embodied a dramatic break in terms of scope, expense, ambition, infrastructure and price with Flamingo and 12 West. Consequently the Saint suggested an at least partial shift in the framework of the dance floor experience from one of participation to one of consumption, for while venues needed to cover their costs, the much higher entry price at the Saint brought this relationship to the fore. The dance experience shifted accordingly from a communal activity that relied on a necessary financial contribution to one that raised a series of customer expectations. When those expectations were not met-because, perhaps, a DJ didn't play the right record at the right moment-complaints were raised in the register of the consumer who believes that money should be able to purchase an object or experience that is of equivalent value, and that some form of redress should follow disappointment. In response, Mailman introduced a range of strategies that, whether intended or not, had the effect of defining the Saint product more rigorously.

The fragmentation and commodification of the wider music scene in New York accentuated the uniqueness-bordering-on-isolation of Mailman's venue. Across the period Saint spinners received fewer and fewer offers to play in alternative spots, and Leslie expressed his regret at this development in his interview with the New York Native (Park 1983: 37) in June 1983. "Gay music is a very specialized sound, and once you become fluent with it you lose contact with all the other things that are going on musically", he noted. "You tend to get a little too narrow. That is the benefit of playing at a black club or a straight club: broadening yourself". In fact "gay music" could coincide with music recorded by African Americans, as Levan demonstrated on a weekly basis at the Paradise Garage, and Leslie had himself drawn regularly on the kind of music that was being played in black and Latin clubs when he started DJing in the late 1970s. In addition to playing records by the likes of Ashford \& Simpson, First Choice, Gloria Gaynor, Loleatta Holloway, Grace Jones, Eddie Kendricks, Love Unlimited Orchestra, the O’Jays, Harold Melvin \& the Bluenotes, Diana Ross, Sister Sledge, the Three Degrees, the Trammps, Two Tons o' Fun and Barry White regularly, Leslie made Jimmy Ruffin's "Hold On to My Love" his signature anthem. Yet Leslie was less drawn to post-disco African American music, which sounded funkier, rougher and relatively downtempo, and the rupture became marked across 1983 . "We resisted the format change in the New York market", he comments. "The boys liked their $R \& B$, but preferred it to be more soulful and Philly-influenced. With the exception of just 
a few isolated tracks, the new sound just wasn't 'pretty' enough for them. It was too 'raw' and stripped down". ${ }^{27}$

Convinced that the Garage was a much more promising place to test new music, and also that Hi-NRG would never sell domestically, record company promoters who had besieged Flamingo and 12 West during the 1970s disengaged with the Saint. In turn, Billboard calculated that Hi-NRG didn't deserve a great deal of coverage, and dance chart compiler and reporter Brian Chin proceeded to take his cues from "black DJs" and a "token representation of Fire Island gay DJs" because the latter group was "playing to no discernible effect to the rest of the industry". He adds: "I had a very retrograde attitude of Saint music, and I was wrong not to recognize it. But I was fighting to create a context in which club music still had a place in the music industry". ${ }^{28}$ The foreign location of the record companies that were releasing Hi-NRG also meant that in contrast to DJ-remixers such as Jim Burgess and Tom Savarese, who stamped their imprint on an array of high profile domestic disco releases during the 1970s, and also Junior Vasquez, who would go on to become an influential house remixer in the early 1990s, Leslie and his peers weren't able to establish an equivalent studio foothold from which they could reshape the sound of music.

The acceleration of the AIDS epidemic across the early 1980s entrenched the Saint crowd's sense of its own specificity and isolation still further. Identified in 1981, named in 1982, categorised as an epidemic in 1983, and linked to the virus that would be named HIV in 1984, AIDS hit the Saint more intensely than any other dance venue because a high proportion of its dancers engaged in unprotected promiscuous sex. The promiscuity had been allowed if not encouraged by the venue, where dancers would elope to an unpoliced upstairs balcony to engage in sex. AIDS was even nicknamed "Saint's disease" (Shilts 1987: 149) early on because of the marked proliferation of the disease among Mailman's membership. Initially the Saint crowd carried on as if the disease was an unpleasant mutation of other pernicious but usually non-fatal sexually-transmitted diseases that had circulated in the gay male community with increasing preponderance across the 1970s, and an early fundraiser held at the venue was criticised for directing the bulk of the proceeds to the cost of staging the event. But across the 1983-84 season the threat of the disease became better understood, dancers started to change their habits, and a siege mentality began to take hold when gay campaigners criticised the governmental response to the crisis for being too slow while attempting to deflect the rise in homophobic hate on the part of moral majority representatives. ${ }^{29} \mathrm{Within}$ this context, the pre-AIDS sound of disco came to embody a nostalgic moment in which unprotected sex didn't carry the threat of death, even if its recycling added force to the argument that the Saint was trapped in time.

For these and other reasons, music industry reps might have disengaged even more than they would have done in other circumstances. "Because all the early victims of AIDS were gay, white males, it was no longer considered 'cool' by straight people in the domestic record industry to dance in gay, white clubs", argues Sherman. "It was definitely homophobia, although perfectly understandable since nobody knew what it was, where it came from, or how you could 'catch' it, and there was a bit of reverse-racism thrown in for good measure. 
Hanging with white gay males was definitely not sexy by 1983 " ${ }^{30}$ If the white gay community's disengagement from the concerns of other groups in the countercultural coalition left it more isolated politically than would have been the case if those early affiliations had been maintained, responsibility for the drift also lies elsewhere, for while white gay men might have been slow to engage with civil rights and the concerns of black gay men across the 1970s, the leaders of the African American community were also reluctant to address the problem of black homophobia along with the wider need to campaign for gay civil rights. The Saint remained the most homogeneous of all of New York's clubbing communities of the early 1980s, and the venue's lack of engagement with sonic and social diversity in the post-1983 period left its membership more vulnerable and stranded than it might have been when the AIDS crisis spiralled.

Several factors led to the weakening of the demographic and aesthetic convergence around whiteness, gayness and masculinity that had been forged across the 1983-84 season. First, the decimation of his membership by AIDS across the second half of the 1980s prompted Mailman to reduce the cost of entry in order to boost numbers, and as a result a younger, less economically privileged group of dancers who had less of an affinity with classic disco and were more open to new sounds started to head to the venue. Second, Mailman closed the Saint in 1988 not only because it had become much more difficult to fill the floor, but also because inflation in the real estate market (which paralleled the rise of the stock market) meant that this was the best way for him to pay off his investors. Third, the diminution of the crowd along with the added cost of opening a new venue prompted future owners to develop less expensive, less tightly controlled clubs, which in turn undermined the likelihood that the remainder of the "A-list" would find an equivalent home. Finally, Saint DJs (aside from Sherman) had ignored the flow of house music from Chicago to New York across 1985-88 because they judged the sound to be "too rough" or "too black", but across those four years the sound established itself as the irrefutable successor-genre to disco in New York as well as many European cities, and when Junior Vasquez championed a hard, tribal variation of the sound at the Sound Factory between 1989-95, he carried a significant proportion of the surviving Saint membership with him.

\section{INFLUENCE}

THE SHIFTING CONTOURS OF THE WHITE GAY DANCE MILIEU across the post-1988 period shouldn't be allowed to obscure the originality, power and influence of the Saint. Moreover, while house music would go on to become the dominant sound of dance in many countries during the 1990s, the genre failed to break out of the club milieu with anything like the force of 1970s disco in the US, whereas the Hi-NRG sound popularized at the Saint was picked up much more readily. The commercial success of Hi-NRG might have weakened the cultural capital of the Saint, yet the popularity of the sound remains an indicator of the venue's capacity to, if not generate new trends, then at least align itself with their emergence. In addition, while the infrastructure of Mailman's venue was effectively irreproducible, the Saint attracted notable numbers of dancers from other states in the US as well as Europe, 
and Ian Levine (to quote one example) has gone on to recount (Brewster 1999) how he attempted to replicate the Saint's musical agenda at Heaven, which was arguably the leading gay nightspot in London during the 1980s and 1990s (in a tangential move, the owners of the Ministry of Sound would model their venue on the Paradise Garage).

More broadly, Saint DJs were among the first to prioritize a style of DJing that emphasized the seamless linking of tracks that differed only slightly in terms of their aesthetic content, and this style would become the dominant practice in house culture, in which DJs broke with the practice of Levan and Mancuso, as well as figures such as Afrika Bambaataa (the Roxy) and Jellybean Benitez (the Funhouse), who developed a pluralistic style that could lead them to juxtapose contrasting tracks. Even if the Saint DJs didn't directly inspire the broader shift to the infinite aesthetic of "house music all night long" - and their early disengagement from house indicates that they didn't - their forging of a milieu that brought together sonic repetition, smooth mixing and drug consumption was anticipatory if not visionary. That the Saint helped establish an early version of the kind of trance-oriented seamlessness that would become so popular in club and rave circuits also indicates that the assumed influence of Levan on contemporary dance culture requires a more nuanced analysis. As it is, the Saint DJs have for the most part drifted into historical anonymity, with the part exception of Robbie Leslie. If their profile might have been higher had they matched Levan's partial embrace of house, the coincidence of a complex range of contingent circumstances explains why such a move was always unlikely.

\section{ENDNOTES}

1 See Bill Brewster and Frank Broughton (1999), Fiona Buckland (2002), Matthew Collin with John Godfrey (1997), Kai Fikentscher (2000), Sheryl Garratt (1998), Ulf Poschardt (1998), Simon Reynolds (1998) and Peter Shapiro (2005). Brewster and Broughton,

Buckland and Shapiro devote some space to the Saint, but restrict their account of the DJs to a paragraph at most. The historians of US gay culture Clendinen and Nagourney (1999) provide a rare reference to the Saint (1999: 446-7) yet focus on the club's infrastructure and membership regulations. Charles Kaiser (1997: 283) references the Saint (but not its DJs) in passing. I chart Larry Levan's playing career in detail in my first monograph, Love Saves the Day: A History of American Dance Music Culture, 1970-79. I pick up the story in my third monograph, which is provisionally titled Life and Death on the New York Dance Floor: A History, 1980-84, forthcoming with Duke University Press. See also Mel Cheren (2000) for a personal recollection of Levan's life.

2 Although not all are quoted directly, I am grateful to Brian Chin, Michael Fesco, John Giove, Stuart Lee, Jorge La Torre, Robbie Leslie, Howard Merritt, Mann Parrish, Terry Sherman, Marsha Stern, Barry Walters and Sharon White for agreeing to be interviewed, some of them several times over. I'd also like to thank Stephen Pevner of the Saint-at-Large for providing access to the Saint archive's collection of posters, DJ schedules, in-house journals and digital files of DJ sets by Shaun Buchanan, Jim Burgess, Robbie Leslie, Howard Merritt, Terry Sherman and Roy Thode, which informed much of this article. I'm also grateful to Marsha 
Stern for providing additional recordings of Roy Thode's DJ sets, and to Conor Lynch for providing additional information on his own collection of recorded DJ sets from the Saint.

3 According to InflationData.com, inflation from October 1980 to October 2010 totals $157.91 \%$, so the $\$ 125$ membership would have cost $\$ 322.38$ in 2010 , the $\$ 10$ entry for members $\$ 25.79$, and the $\$ 18$ charge for non-members $\$ 46.42$. The cost of a new (rather than a renewed) membership rose to $\$ 200$ for the 1981-82 season.

4 Author telephone interview with Sharon White, 16 March 2009.

5 Author email interview with Terry Sherman, 4 December 2010.

6 Author interview with Jorge La Torre, New York, 18 February 2009. All subsequent quotes from La Torre are drawn from this interview.

7 A range of figures are quoted in Claudia Cohen and Cyndi Stivers (1980), Nathan Fain (1980) and Jan Hodenfield (1980). The quote is drawn from an author interview with Terry Sherman, 4 December 2010.

8 Author email interview with Terry Sherman, 4 December 2010.

9 Author telephone interview with Robbie Leslie, 23 October 2008.

10 Although her focus isn't the dance floor dynamic, Fiona Buckland (2002) provides a useful account of the Saint as a space of queer affirmation through an interview with a member called Tito.

11 Author telephone interview with Howard Merritt, 21 January 2009. All subsequent quotes from Merritt are drawn from this interview.

12 Author telephone interview with Marsha Stern, 19 November 2008.

13 Sherman notes that Parsons was regularly asked to play big parties including "Opening Night", "Halloween", "New Year's Eve", the "Black Party" and "Closing Night". Leslie was the regular DJ at the "White Party". A range of DJs would step in for "Night People", "Christmas", "Land of Make Believe", "Disco Day", "Summer Opening", "Summer Closing” and the Memorial Day party, which took on different titles.

14 Jeff Dupre unpublished interview with Michael Fierman, no date. Courtesy of Stephen Pevner. Minor edits introduced.

15 Author telephone interview with Robbie Leslie, 23 October 2008.

16 Author telephone interview with Sharon White, 30 April 2009. All subsequent quotes from White are drawn from this interview.

17 A detailed analytical account of the disco sucks movement can be found in Lawrence (2003: 363-401). See also, Shapiro (2005: 226-32).

18 Marsha Stern holds the original copy of Roy Thode's “The BPM (Beats Per Minute) Bible”.

19 Roy Thode set at the Black Party, the Saint, held in early 1981. MP3 recording provided by Marsha Stern.

20 Thode appealed for dancers to be more tolerant of the Saint DJs in an article he published (Thode 1982) in the first edition of Stardust, the Saint's in-house journal.

21 Author telephone interview with Marsha Stern, 15 December 2008.

22 Author telephone interview with Marsha Stern, 19 November 2008.

23 Michael Fierman interview with Dupre for an unfinished documentary about the Saint, undated. The original transcript is held by Stephen Pevner. A copy of the transcript is held by the author. 
24 Author telephone interview with Barry Walters, 29 September 2009.

25 Author email interview with Terry Sherman, 20 April 2009.

26 Author email interview with Robbie Leslie, 7 April 2009.

27 Author email interview with Robbie Leslie, 15 March 2006.

28 Author interview with Brian Chin, New York City, 9 February 1998.

29 See, for example, Larry Kramer's article "1,112 and Counting" in the New York Native, 14 March 1983. While some AIDS activists in the Gay Men's Health Crisis deemed Kramer too contentious, in part because of his repeated critique of what he perceived to be excessive gay hedonism, the article is also seen as a key moment in the raising of AIDS awareness.

30 Author email interview with Terry Sherman, 8 April 2009.

\section{REFERENCES}

Appadurai, Arjun. 1996. Modernity at Large: Cultural Dimensions of Globalization. Minneapolis: University of Minnesota Press.

Brewster, Bill. 1999. "Ian Levine”. DJhistory.com. 2 March: < http://www.djhistory.com/ interviews/ian-levine> (accessed 21 July 2009).

Brewster, Bill and Frank Broughton. 1999. Last Night A DJ Saved My Life: The History of the Disc Jockey. London: Headline.

Buckland, Fiona. 2002. Impossible Dance: Club Culture and Queer World-Making. Middletown, Connecticut: Wesleyan University Press.

Cheren, Mel. 2000. My Life and the Paradise Garage: Keep On Dancin'. New York: 24 Hours for Life.

Chin, Brian. 1982. "Dance Trax". Billboard, 19 June: 48.

Clendinen, Dudley, and Adam Nagourney. 1999. Out for Good: The Struggle to Build a Gay Rights Movement in America. New York: Simon \& Schuster.

Cohen, Claudia and Cyndi Stivers. 1980. “I, Claudia”. New York Daily News, 15 September.

Collin, Matthew with contributions by John Godfrey. 1997. Altered State: The Story of Ecstasy Culture and Acid House. London: Serpent's Tail.

Combahee River Collective. 1977. "The Combahee River Collective Statement”. <http:// circuitous.org/scraps/combahee.html> (accessed 20 November 2010).

Fain, Nathan. 1980. “The New Boogie Merchants”. After Dark, September: 47-51.

Fikentscher, Kai. 2000. "You Better Work!" Underground Dance Music in New York City. Hanover and London: Wesleyan University Press.

Garratt, Sheryl. 1998. Adventures in Wonderland: A Decade of Club Culture. London: Headline.

Haden-Guest, Anthony. The Last Party: Studio 54, Disco, and the Culture of the Night. New York: William Morrow and Company, 1997.

Hodenfield, Jan. 1980. “A Gay Disco on a Grand Scale”. New York Daily News. 17 November. Hughes, Walter. 1994. "In the Empire of the Beat: Discipline and Disco". In Microphone Fiends: Youth Music and Youth Culture, eds. Andrew Ross and Tricia Rose, 147-54. London: Routledge.

Kaiser, Charles. 1997. The Gay Metropolis, 1940-1996. London: Weidenfeld and Nicolson. 
Kramer, Larry. 1983. "1,112 and Counting”. New York Native, 14 March: < http://la.indymedia. org/news/2003/05/58757.php>. Posted 20 May 2003 (accessed 20 October 2010).

Lawrence, Tim. 2003. Love Saves the Day: A History of American Dance Music Culture, 1970-79. Durham and London: Duke University Press.

Park, Jan Carl. 1983. “The A-Gay's Disc Jockey: Robbie Leslie and the Politics of the Turntable”. New York Native, 20 June: 36-37.

Poschardt, Ulf. 1998. DJ Culture. Trans. Shaun Whiteside. London: Quartet Books.

Reynolds, Simon. 1998. Energy Flash: A Journey Through Rave Music and Dance Culture. London: Picador.

Ritzer, George. 1999. Enchanting a Disenchanted World: Revolutionising the Means of Consumption. Thousand Oaks, London, New Delhi: Pine Forge Press.

Shapiro, Peter. 2005. Turn the Beat Around: The Secret History of Disco. London: Faber and Faber.

Shilts, Randy. 1987. And the Band Played On: Politics, People, and the AIDS Epidemic. New York: St. Martin's Press.

Thode, Roy. 1982. “A Letter From a DJ”. Star Dust. Spring: 2.

- - - n.d. The BPM (Beats Per Minute) Bible. Unpublished notepad. Original copy held by Marsha Stern.

Wallerstein, Immanuel. 1983. Historical Capitalism. New York: Verso.

\section{DISCOGRAPHY}

ABBA. 1981. The Visitors. Atlantic (vinyl): SD 19332. <http://www.discogs.com/ABBA-The-Visitors/release/842292>

Azul Y Negro. 1982. "La Noche (The Night)”. Mercury (vinyl): 6400749. <http://www.discogs.com/Azul-Y-Negro-The-Night-La-Noche/release/201140>

Bent Boys. 1981. "Walk The Night". White label (vinyl) later released by J.C. Records (vinyl): JC12-024. <http://www.discogs.com/Bent-Boys-Walk-The-Night/release/1668836>

Branigan, Laura. 1982. "Gloria”. Atlantic (vinyl): DM 4835. <http://www.discogs.com/Laura-Branigan-Gloria/release/414822>

Bridges, Alicia. 1978. "I Love The Nightlife (Disco 'Round)". Polydor (vinyl): PD D 503. <http://www.discogs.com/Alicia-Bridges-I-Love-The-Nightlife-Disco-Round/ release $/ 138768>$

Brown, Miquel. 1983. “So Many Men, So Little Time”. TSR Records (vinyl): TR102. <http://www.discogs.com/Miquel-Brown-So-Many-Men-So-Little-Time/release/791310>

Change. 1980. "A Lover's Holiday”. RFC Records (vinyl): PRO-A-854. < http://www.discogs.com/Change-A-Lovers-Holiday/release/643003>

Clifford, Linda. 1978. "Runaway Love". Curtom (vinyl): PRO-A-731. <http://www.discogs.com/Linda-Clifford-Runaway-Love/release/745990>

Cowley, Patrick, featuring Sylvester. 1982. “Do Ya Wanna Funk”. Megatone Records (vinyl): MT 102. <http://www.discogs.com/Patrick-Cowley-Featuring-Sylvester-Do-Ya-Wanna-Funk/ release/2190101>

Devo. 1983. “That's Good”. Warner Bros. Records (vinyl): PRO-A-2006. < http://www.discogs.com/Devo-Thats-Good/release/578360> 
Gardner, Taana. 1981. "Heartbeat". West End Records (vinyl): WES-22132. <http://www.discogs.com/Taana-Gardner-Heartbeat/release/77606>

Cut Glass. 1980. “Without Your Love”. 20th Century Fox Records (vinyl): TCD-103-DJ. < http://www.discogs.com/Cut-Glass-Without-Your-Love/release/411974>

Grandmaster and Melle Mel. 1983. "White Lines”. Sugar Hill Records (vinyl): SH 465. <http://www.discogs.com/Grandmaster-Melle-Mel-White-Lines-Dont-Dont-Do-It/ release $/ 940478>$

Griffin, Peter. 1980. “Step By Step”. Electrola (vinyl): 1C 052-46 249 YZ. <http://www.discogs.com/Peter-Griffin-Step-By-Step/release/1339959>

Guthrie, Gwen. 1983. "Padlock”. Garage Records (vinyl): ITG 2001. <http://www.discogs.com/Gwen-Guthrie-Padlock/release/29296>

Idol, Billy. 1982. "White Wedding". Chrysalis (vinyl): AS 1699. <http://www.discogs.com/Billy-Idol-White-Wedding-Live/release/2237068>

Jiani, Carol. 1981. "Hit 'N Run Lover”. Matra Records (vinyl): W-12044. <http://www.discogs.com/Carol-Jiani-Hit-N-Run-Lover-All-The-People-Of-The-World/ release/1621693>

Kane, Madleen. 1979. "Secret Love Affair". Pye Records (vinyl): 12P 5007. <http://www.discogs.com/Madleen-Kane-Secret-Love-Affair/release/695138>

Khan, Chaka. 1980. "Clouds". Warner Bros. Records (vinyl): K 17617T. <http://www.discogs.com/Chaka-Khan-Clouds/release/328334 >

Lime. 1982. "Come And Get Your Love". Unidisc (vinyl): SPEC-1206. <http://www.discogs.com/Lime-Come-And-Get-Your-Love/release/2764582>

Marie, Kelly. 1979. "Feels Like I'm In Love”. Calibre + Plus! (vinyl): PLUSL 1. <http://www.discogs.com/Kelly-Marie-Feels-Like-Im-In-Love/release/399509>

Marie, Tina. 1981. “Square Biz”. Motown (vinyl): 12TMG 1236. <http://www.discogs.com/Teena-Marie-Square-Biz/release/211302>

Moroder, Giorgio, with Helen Terry. 1984. “Now You're Mine”. Virgin (vinyl): VS 710-12. < http://www.discogs.com/Giorgio-Moroder-With-Helen-Terry-Now-Youre-Mine/ release/447459>

Nelson, Phyllis. 1981. "Don't Stop The Train”. Tropique Records (vinyl): TD 104. <http://www.discogs.com/Phyllis-Nelson-Dont-Stop-The-Train/release/437668>

Newton-John, Olivia. 1980. “Magic”. Jet Records (vinyl): JET P 196. <http://www.discogs.com/Olivia-Newton-John-Magic/release/977732>

- — . 1983. "Twist Of Fate”. MCA Records (vinyl): L33-1150. <http://www.discogs.com/Olivia-Newton-John-Twist-Of-Fate/release/1093193 >

Ozo. 1976. "Anambra”. DJM Records (vinyl): DJT 10764. <http://www.discogs.com/Ozo-Anambra/release/318739>

Passengers. 1981. "Hot Leather". Moby Dick Records (vinyl): MDR-1206. < http://www.discogs.com/Passengers-Hot-Leather/release/173698>

Pitney, Gene. 1961. “Town Without Pity”. His Master's Voice (vinyl): 45-POP 952. $<$ http://www.discogs.com/Gene-Pitney-Town-Without-Pity-Air-Mail-Special-Delivery/ release $/ 1756713>$ 
Pointer, Bonnie. 1979. "Heaven Must Have Sent You”. Motown (vinyl): M 00020 D1. <http://www.discogs.com/Bonnie-Pointer-Heaven-Must-Have-Sent-You/release/424445>

Rational Youth. 1983. "City Of Night”. Rams Horn Records (vinyl): RAMSH 12-3187. <http://www.discogs.com/Rational-Youth-City-Of-Night/release/226105>

Redd, Sharon. 1981. “Can You Handle It?” Prelude Records (vinyl): PRL D 611-BS. $<$ http://www.discogs.com/Sharon-Redd-You-Got-My-Love-Can-You-Handle-It/ master/118211>

Ripple. 1977. “The Beat Goes On And On”. Salsoul Records (vinyl): SG 2057. < http://www.discogs.com/Ripple-The-Beat-Goes-On-And-On-Facts-Of-Life/release/7473>

Ruffin, Jimmy. 1980. "Hold On To My Love”. RSO Records (vinyl): 2394258. <http://www.discogs.com/Jimmy-Ruffin-Sunrise/release/1355589>

Serious Intention. 1984. "You Don't Know". Easy Street Records (vinyl): EZS-7512. <http://www.discogs.com/Serious-Intention-You-Dont-Know/release/605355>

Shaw, Marlena. 1979. “Touch Me In The Morning”. Columbia (vinyl): AS 678. <http://www.discogs.com/Marlena-Shaw-Touch-Me-In-The-Morning/release/879538>

Springsteen, Bruce. 1984. "Dancing In The Dark”. Columbia (vinyl): 4405028. <http://www.discogs.com/Bruce-Springsteen-Dancing-In-The-Dark/release/921430>

Stewart, Rod. 1978 “Da Ya Think I'm Sexy? (Special Disco Mix)”. Warner Bros. Records (vinyl): WBSD 8727.<http://www.discogs.com/ Rod-Stewart-Da-Ya-Think-Im-Sexy-Special-Disco-Mix/release/2193304>

———. 1980. "Passion". Warner Bros. Records (vinyl): PRO-A-921. <http://www.discogs.com/Rod-Stewart-Passion/release/412030>

Talking Heads. 1979. "I Zimbra”. Sire Records Company (vinyl): PRO-A-846. <http://www.discogs.com/Talking-Heads-I-Zimbra/release/791875>

Tantra. 1979. "The Hills Of Katmandu”. Philips (vinyl): 9198334. <http://www.discogs.com/Tantra-Hills-Of-Katmandu-Wishbone/release/212461>

Tempers. 1984. "No Favors". MCA Records (vinyl): MCA-23506. <http://www.discogs.com/Temper-No-Favors/release/485753>

Thomas, Evelyn. 1984. "High Energy". Record Shack Records (vinyl): SOHOT 18. <http://www.discogs.com/Evelyn-Thomas-High-Energy/release/137040>

Tyler, Bonnie. 1984. "Holding Out For A Hero". CBS (vinyl): TA 4251. <http://www.discogs.com/Bonnie-Tyler-Holding-Out-For-A-Hero/release/645293>

Van Halen. 1983. “Jump”. Warner Bros. Records (vinyl): W 9384 (T). <http://www.discogs.com/Van-Halen-Jump/release/503048>

Voyage. 1978. "Souvenirs". T.K. Disco (vinyl): 117. <http://www.discogs.com/Voyage-Souvenirs-Tahiti-Tahiti/release/180896>

Weather Girls. 1982. "It's Raining Men”. Columbia (vinyl): 44-03181. <http://www.discogs.com/Weather-Girls-Its-Raining-Men/release/352519>

Wills, Viola. 1982. "Stormy Weather". Sunergy (vinyl): SNG-0001. <http://www.discogs.com/Viola-Wills-Stormy-Weather/release/345337>

Young, Karen. 1978. "Hot Shot”. West End Records (vinyl): WES 1211. <http://www.discogs.com/Karen-Young-Hot-Shot/release/79289> 